\title{
Soil-plant relationship in Calluna heathlands after experimental burning and nitrogen fertilization, studies from NW Spain
}

\author{
Elena Marcos, Angela Taboada, Leonor Calvo \\ Area of Ecology, University of León, 24071 León, Spain, \\ e-mail: elena.marcos@unileon.es
}

\begin{abstract}
We studied changes in the relationship between soil nutrient content and plant species richness in Calluna heathlands after seven years of experimental burning (B) and nitrogen fertilization (NF). Our results indicate that both the treatments (B, NF, B+NF) and modification of several soil characteristics (total $\mathrm{N}$, available $\mathrm{Na}$, and $\mathrm{C}: \mathrm{N}$ ratio) reflected in a significant increase in plant species richness.
\end{abstract}

Key words: Calluna vulgaris, Cantabrian heathlands, Nutrients, species richness, soil chemistry.

\section{Introduction}

Nitrogen $(\mathrm{N})$ deposition is a major threat to biodiversity, but its effects may vary greatly among habitat types (Bobbink et al., 2010). Different studies have pointed out that $\mathrm{N}$ deposition causes severe declines in species richness, mainly in mountain habitats (Roth et al., 2013; Armitage et al., 2014), such as montane heathlands. $\mathrm{N}$ effect can be, however, altered by the interaction with fire (Britton et al., 2008) to enhance the impact of both drivers on heathland soils (Green et al., 2013).

In this study we investigated the effects of burning, $\mathrm{N}$ fertilization, and burning plus $\mathrm{N}$ fertilization on plant species richness and soil characteristics, with the aim of answering three questions: (i) how does species richness change in relation to these treatments?, (ii) does burning plus $\mathrm{N}$ fertilization alter the magnitude of these changes?, (iii) which soil characteristics are responsible for species richness variation?

\section{Study area}

Three Calluna heathland sites were selected in the Cantabrian Mountains (NW Spain): Riopinos I (1653 m a.s.l.), Riopinos II (1567 m) and San Isidro (1636 m). This area has a Eurosiberian climate with a mean annual precipitation of $1319.5 \mathrm{~mm}$ and a mean annual temperature of $5.5^{\circ} \mathrm{C}$. Soil is covered by snow five months per year. Soils are Umbrisols developed over shales and sandstones (San Isidro) and quartzite rocks (Riopinos I and Riopinos II). Vegetation is dominated by Calluna vulgaris (63\% cover), accompanied by Erica tetralix (25\%) and Vaccinium myrtillus (5\%).

\section{Materials and Methods}

A randomised block design was used to investigate the influence of two driving variables (burning and $\mathrm{N}$ fertilization) on plant species richness and soils. Four permanent plots $(20 \times 20 \mathrm{~m})$ were placed in each heathland site. One plot per site was subjected to $\mathrm{N}$ addition (NF) $(56 \mathrm{~kg}$ $\mathrm{N} \mathrm{ha}^{-1} \mathrm{yr}^{-1}$ ) from 2005 until 2014, the second plot to burning (B) in June 2005, the third plot to burning plus $\mathrm{N}$ addi- 
tion $(\mathrm{B}+\mathrm{NF})$, and the fourth one was used as a control (C). The fertilization level was chosen to be equivalent to twice the estimated current background pollution levels in this area. In each plot, ten permanent sampling units $(1 \times 1 \mathrm{~m})$ were established. Seven years after the treatments, all the plant species present in each unit were recorded and soil samples from all units were taken at a depth of $5 \mathrm{~cm}$. Afterwards, they were analysed for $\mathrm{pH}$, organic carbon, total $\mathrm{N}, \mathrm{C}: \mathrm{N}$ ratio, available $\mathrm{P}, \mathrm{Ca}, \mathrm{K}, \mathrm{Na}$ and $\mathrm{Mg}$. The statistical correlation of potential predictor variables (soil characteristics) with the response variable (species richness) was evaluated using a GLM. The response was assumed to follow a Poisson distribution with a log-link function. The optimal model was identified by selection of the model with the lowest AIC (Akaike's Information Criterion). All statistical analyses were implemented in R (R Development Core Team, 2014).

\section{Results and discussion}

Both burning (B) and $\mathrm{N}$ fertilization (NF) increased plant species richness compared to the control (Fig. 1). However, we only detected a significant increase in number of species in the $\mathrm{B}+\mathrm{NF}$ treatment $\left(\mathrm{F}_{3,116}=5.22 ; \mathrm{P}<0.05\right)$. Seven years after B and NF deposition, there was a decrease in the values of all soil characteristics (Table 1), except in the $\mathrm{B}+\mathrm{NF}$ treatment that showed an important increase in organic $\mathrm{C}$, total $\mathrm{N}$, available $\mathrm{P}, \mathrm{Ca}$ and $\mathrm{K}$. According to the results of the GLM $\left(\mathrm{R}^{2}=56 \%\right)$, both the experimental treatments and soil characteristics (total $\mathrm{N}$, available $\mathrm{Na}$, and $\mathrm{C}: \mathrm{N}$ ratio) significantly $(\mathrm{P}<0.001)$ affected plant species richness.

In Calluna heathlands, burning and $\mathrm{N}$ fertilization augment plant species richness, more pronouncedly so for the combination of both treatments. Such increase in plant species richness is caused by changes on soil nutrients (mainly

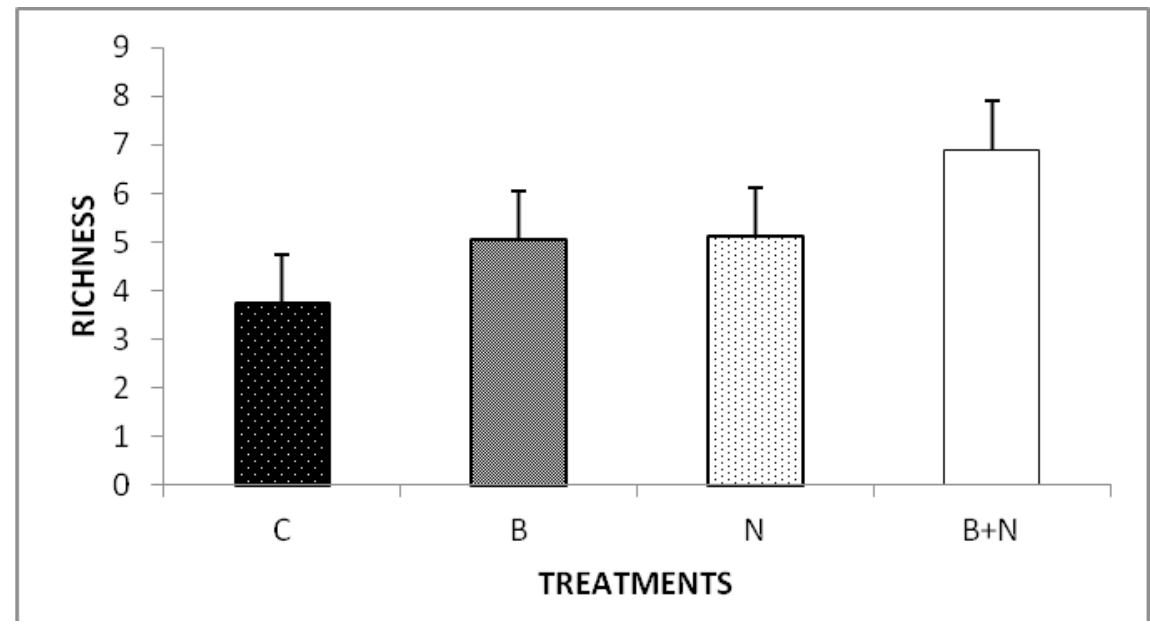

Figure 1. Mean values and standard errors $(n=120)$ for the last sampling year of number of species for each treatment $(\mathrm{C}=$ control, $\mathrm{B}=$ burning, $\mathrm{NF}=$ nitrogen fertilization, $\mathrm{B}+\mathrm{NF}=$ burning + nitrogen fertilization)

Table 1. Mean values and standard errors $(\mathrm{n}=120)$ for the last sampling year of soil characteristics for the different treatments

\begin{tabular}{|c|c|c|c|c|c|c|c|c|c|}
\hline Treatment & $\mathrm{pH}$ & $\mathrm{C} \mathrm{( \% )}$ & $\mathrm{N} \mathrm{( \% )}$ & $\mathrm{C}: \mathrm{N}$ & $\begin{array}{c}\mathrm{P} \\
\left(\mathrm{mg} \mathrm{kg}^{-1}\right)\end{array}$ & $\begin{array}{c}\mathrm{Ca} \\
\left(\mathrm{cmol} \mathrm{kg}^{-1}\right)\end{array}$ & $\begin{array}{c}\mathrm{Mg} \\
\left(\mathrm{cmol} \mathrm{kg}^{-1}\right)\end{array}$ & $\begin{array}{c}\mathrm{K} \\
\left(\mathrm{cmol} \mathrm{kg}^{-1}\right)\end{array}$ & $\begin{array}{c}\mathrm{Na} \\
\left(\mathrm{cmol} \mathrm{kg}^{-1}\right)\end{array}$ \\
\hline Control & $\begin{array}{c}3.85 \\
(0.06)\end{array}$ & $\begin{array}{c}8.49 \\
(0.38)\end{array}$ & $\begin{array}{c}0.41 \\
(0.06)\end{array}$ & $\begin{array}{c}21.8 \\
(2.4)\end{array}$ & $\begin{array}{c}23.34 \\
(5.24)\end{array}$ & $\begin{array}{c}1.19 \\
(0.12)\end{array}$ & $\begin{array}{c}0.39 \\
(0.05)\end{array}$ & $\begin{array}{c}0.64 \\
(0.02)\end{array}$ & $\begin{array}{c}0.04 \\
(0.01)\end{array}$ \\
\hline \multirow{2}{*}{$\mathrm{N}$ fertilization } & $\begin{array}{c}4.05 \\
(0.11)\end{array}$ & $\begin{array}{c}7.02 \\
(1.05)\end{array}$ & $\begin{array}{c}0.39 \\
(0.10)\end{array}$ & $\begin{array}{c}19.7 \\
(3.5)\end{array}$ & $\begin{array}{c}17.11 \\
(8.40)\end{array}$ & $\begin{array}{c}1.12 \\
(0.20)\end{array}$ & $\begin{array}{c}0.25 \\
(0.04)\end{array}$ & $\begin{array}{c}0.63 \\
(0.11)\end{array}$ & $\begin{array}{c}0.03 \\
(0.01)\end{array}$ \\
\hline Burning & $\begin{array}{c}3.93 \\
(0.06)\end{array}$ & $\begin{array}{c}7.29 \\
(1.42)\end{array}$ & $\begin{array}{c}0.38 \\
(0.07)\end{array}$ & $\begin{array}{c}19.9 \\
(3.5)\end{array}$ & $\begin{array}{c}22.81 \\
(8.70)\end{array}$ & $\begin{array}{c}0.85 \\
(0.20)\end{array}$ & $\begin{array}{c}0.29 \\
(0.06)\end{array}$ & $\begin{array}{c}0.46 \\
(0.06)\end{array}$ & $\begin{array}{c}0.03 \\
(0.00)\end{array}$ \\
\hline $\begin{array}{c}\text { Burning + N } \\
\text { fertilization }\end{array}$ & $\begin{array}{c}4.00 \\
(0.12)\end{array}$ & $\begin{array}{c}9.56 \\
(2.12)\end{array}$ & $\begin{array}{c}0.60 \\
(0.22)\end{array}$ & $\begin{array}{c}18.0 \\
(3.0)\end{array}$ & $\begin{array}{c}30.51 \\
(12.73)\end{array}$ & $\begin{array}{c}1.54 \\
(0.26)\end{array}$ & $\begin{array}{c}0.38 \\
(0.14)\end{array}$ & $\begin{array}{c}0.83 \\
(0.16)\end{array}$ & $\begin{array}{c}0.04 \\
(0.01)\end{array}$ \\
\hline
\end{tabular}


N) and micro-environmental conditions. The highest number of species is due to the presence of native graminoids species which are the most frequent to increase after burning and $\mathrm{N}$ fertilization. We did not detect invasive species in the system as a consequence of the treatments. Changes on soil nutrients remained seven years after treatment, because the regeneration is very slow and the plant biomass cannot ability to sequester these additional nutrients.

\section{References}

Armitage H.F., Britton A.J., van der Wal R., Woodin S.J., 2014, The relative importance of nitrogen deposition as a driver of Racomitrium heath species composition and richness across Europe, Biological Conservation 171: 224-231.

Bobbink R., Hicks K., Galloway J., Spranger T., Alkemade R., Ashmore M., Bustamante M., Cinderby S., Davidson E., Dentener F., Emmett B., Erisman J.W., Fenn M., Gilliam F., Nordin A., Pardo L., de Vries W., 2010, Global assessment of nitrogen deposition effects on terrestrial plant diversity: a synthesis, Ecological Applications 20: 30-59.
Britton A.J., Helliwell R.C., Fisher J.M., Gibbs S. 2008, Interactive effects of nitrogen deposition and fire on plant and soil chemistry in an alpine heathland, Environmental Pollution 156: 409-416.

Green E.R., Ellis R.J., Gadsdon S.R.M., Milcu, A. Power S.A., 2013, How does $\mathrm{N}$ deposition affect belowground recovery following wildfire? Soil Biology \& Biochemistry 57: 775-783

R Development Core Team, 2014, R: A language and environment for statistical computing. R Foundation for Statistical Computing, Vienna, Austria. URL http://www.R-project.org/.

Roth T., Kohlia L., Rihmc B., Achermannd B., 2013, Nitrogen deposition is negatively related to species richness and species composition of vascular plants and bryophytes in Swiss mountain grassland. Agriculture, Ecosystems \& Environment 178: 121-126. 